\title{
ASSOCIATION STUDY OF THE FTO GENE POLYMORPHISMS WITH THE RISK OF PULMONARY TUBERCULOSIS IN A SAMPLE OF IRANIAN POPULATION
}

\author{
MOHAMMAD NADERI $^{1}$, MOHAMMAD HASHEMI ${ }^{2} *$, NAHID DEJKAM ${ }^{1}$, \\ GHOLAMREZA BAHARI $^{2}$, MARYAM REZAEI ${ }^{2}$ and MOHSEN TAHERI ${ }^{3}$ \\ ${ }^{1}$ Infectious Diseases and Tropical Medicine Research Center, Zahedan University of \\ Medical Sciences, Zahedan, Iran \\ ${ }^{2}$ Cellular and Molecular Research Center, Zahedan University of Medical Sciences, \\ Zahedan, Iran \\ ${ }^{3}$ Department of Clinical Biochemistry, School of Medicine, Zahedan University of \\ Medical Sciences, Zahedan, Iran
}

(Received: 7 May 2016; accepted: 24 June 2016)

Aim: The aim of the present study was to find out the impact of fat mass and obesity-associated (FTO) gene on risk of pulmonary tuberculosis (PTB) in a sample of Iranian population. Methods: This case-control study was carried out on a total of 354 subjects including 185 PTB patients and 169 healthy subjects. Genotyping of FTO rs9939609 and rs8050136 variants was done using polymerase chain reactionrestriction fragment length polymorphism method. Results: FTO rs9939609 variant showed no statistically significant difference in allele and genotype frequencies between PTB patients and controls. The rs8050136 polymorphism marginally increased the risk of $\mathrm{PTB}$ in dominant $(\mathrm{OR}=1.53,95 \% \mathrm{CI}=1.00-2.33$, $p=0.055, \mathrm{CA}+\mathrm{AA}$ vs. CC) inheritance model tested, where rs8050136 A allele significantly increased the risk of PTB $(\mathrm{OR}=1.42,95 \% \mathrm{CI}=1.02-1.97$, $p=0.045)$ compared with $\mathrm{C}$ allele. Conclusion: The finding of the present study showed an association between FTO rs9939609 variant and risk of PTB. Further studies with larger sample sizes and different ethnicities are necessary to confirm the findings.

Keywords: tuberculosis, FTO, polymorphism

*Corresponding author; E-mails: mhd.hashemi@gmail.com; hashemim@zaums.ac.ir 


\section{Introduction}

Tuberculosis (TB) is a main health concern, affecting nearly one-third of the world's population [1, 2]. According to WHO report on global TB control, approximately 8.6 million new cases occurred in 2012 [3]. It has been proposed that $5 \%-10 \%$ of infected cases go on to develop active TB [3], which implies that host genetics may influence the risk of the disease. Multiple lines of evidence support a role for genetics in the development of pulmonary tuberculosis (PTB) [4-9] in a sample of Iranian population.

The FTO gene is located on chromosome 16 (16q12.2). This gene encodes a protein that plays a role in regulation of food intake [10]. Obesity influence patterns of oxidative stress and altered circulating levels of inflammatory cytokines, which impair immune function, modify leukocyte counts, and affect cell-mediated immune responses [11-13]. There is growing evidence showing that the impairment of the immune function leads to an increased susceptibility of the host to a number of various pathogens, such as Mycobacterium tuberculosis, influenza, coxsackievirus, Helicobacter pylori, and encephalomyocarditis virus [14-16].

FTO is the strongest known genetic susceptibility locus for obesity. The genetic variants of FTO gene were found to be significantly associated with obesity in diverse populations [17-21].

To the best of our knowledge, there is only one report regarding the impact of FTO gene polymorphisms on tuberculosis risk [22]. Thus, the present study aimed to examine the possible associations between polymorphisms of FTO rs9939609 and rs8050136 variants and susceptibility to PTB in a sample of Iranian population.

\section{Materials and Methods}

\section{Patients}

This case-control study included 185 confirmed PTB patients and 169 unrelated population-based healthy subjects. The cases were selected from PTB patients admitted to a university-affiliated hospital (Bou-Ali Hospital, Zahedan, referral center for TB). The enrolment procedures have been described previously [23]. Briefly, PTB diagnosis was done using clinical symptoms, chest radiography, presence of acid-fast bacilli on a sputum smear, culturing M. tuberculosis organisms, and response to antituberculosis chemotherapy. The project was approved by the local ethics committee of the Zahedan University of Medical 
Sciences, and informed consent was taken from all subjects participated in the study. Blood samples were collected in ethylenediaminetetraacetic acidcontaining tubes from patients and healthy controls, and genomic DNA was extracted using salting out method as described previously [24].

\section{Genotyping}

Genotyping of FTO rs9939609 and rs8050136 polymorphisms was performed using polymerase chain reaction-restriction fragment length polymorphism (PCR-RFLP) method. The set of primer sequences used in this method are shown in Table I. In each 0.2-mL PCR reaction tube, $1 \mu \mathrm{L}$ of genomic DNA $(\sim 100 \mathrm{ng} / \mathrm{mL}), 1 \mu \mathrm{L}$ of each primer $(10 \mu \mathrm{M}), 10 \mu \mathrm{L}$ of $2 \times$ Prime Taq Premix (GeNet Bio, Korea), and $7 \mu \mathrm{L}$ of $\mathrm{ddH}_{2} \mathrm{O}$ were added.

Amplification was done with an initial denaturation step at $95{ }^{\circ} \mathrm{C}$ for $5 \mathrm{~min}$, followed by 30 cycles of $30 \mathrm{~s}$ at $95^{\circ} \mathrm{C}, 30 \mathrm{~s}$ at $60^{\circ} \mathrm{C}$, and $30 \mathrm{~s}$ at $72^{\circ} \mathrm{C}$ with a final step at $72{ }^{\circ} \mathrm{C}$ for $10 \mathrm{~min}$. For rs 9939609 and rs 8050136 genotyping, $10 \mu \mathrm{L}$ of PCR products were digested with DdeI and MseI restriction enzymes (Fermentas, Vilnius, Lithuania), respectively. Then, the fragments were separated by electrophoresis in $2 \%$ agarose gels. For rs 9939609 variant, the A allele was digested into 173- and 27-bp fragments, whereas the T allele was undigested (200-bp fragment) (Figure 1). Regarding rs8050136 variant, the A allele was digested into 182- and 24-bp fragments, whereas the $\mathrm{C}$ allele was undigested (206-bp fragment) (Figure 2).

\section{Statistical analysis}

Statistical analysis was performed using the SPSS 20.0 package software. The differences between the variables were evaluated by $\chi^{2}$-test or independent sample $t$-test according to the data. The associations between genotypes and PTB were estimated by computing the odds ratio (OR) and $95 \%$ confidence intervals $(95 \% \mathrm{CI})$ from logistic regression analyses. A $p$-value of $<0.05$ was considered to be statistically significant.

Table I. The primers used for the detection of FTO gene polymorphisms using PCR-RFLP method

\begin{tabular}{llll}
\hline \multirow{2}{*}{ Polymorphisms } & \multicolumn{1}{c}{ Sequence $\left(5^{\prime}->3^{\prime}\right)$} & $\begin{array}{c}\text { Restriction } \\
\text { enzyme }\end{array}$ & Product size (bp) \\
\hline rs9939609 T>A & F: TAGGTTCCTTGCGACTGCTGTGAACTT & DdeI & $\begin{array}{l}\text { A allele: } 173,27 \\
\text { T allele: } 200\end{array}$ \\
& R: AGCCTCTCTACCATCTTATGTCCAAACA & & A allele: 182,24 \\
rs8050136 C>A & F: ATGCCAGTTGCCCACTGTGGCATT & MseI & $\begin{array}{l}\text { C allele: } 206 \\
\end{array}$ \\
\hline
\end{tabular}




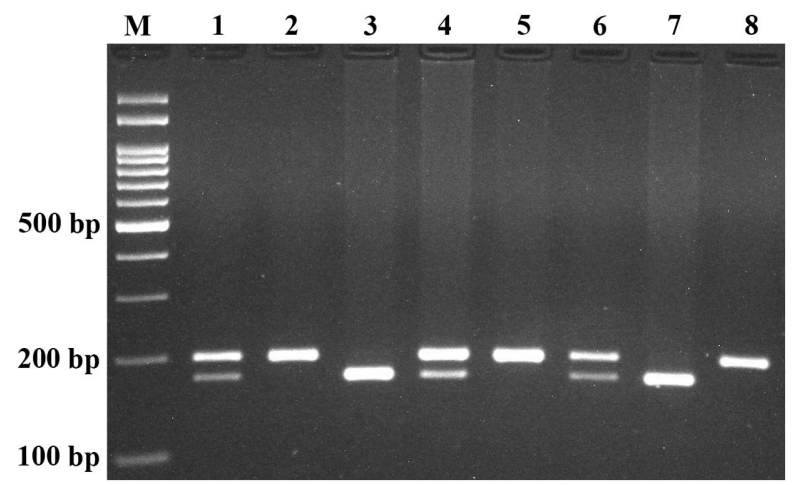

Figure 1. Electrophoresis pattern of PCR-RFLP for the detection of FTO rs9939609 polymorphism. The A allele was digested by DdeI restriction enzyme into 173- and 27-bp fragments, whereas the T allele was undigested (200-bp fragment). M: DNA marker; lanes 1, 4, and 6: TA; lanes 2, 5, and 8: TT; lanes 3 and 7: AA

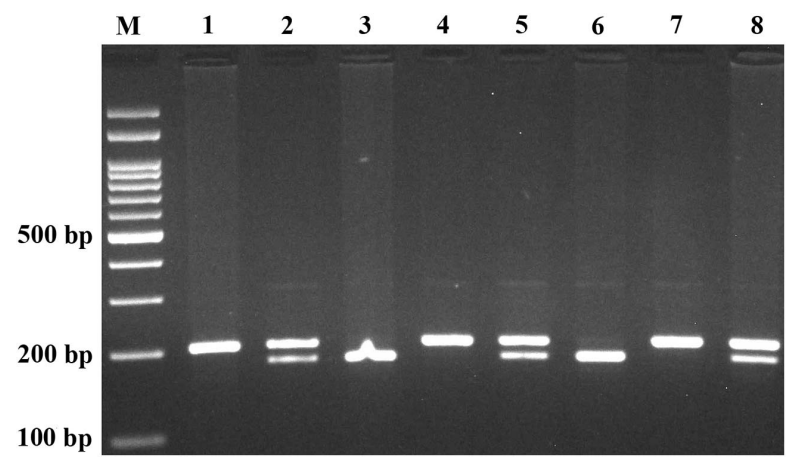

Figure 2. Electrophoresis pattern of PCR-RFLP for the detection of FTO rs8050136 polymorphism. The A allele was digested by MseI restriction enzyme into 182- and 24-bp fragments, whereas the $\mathrm{C}$ allele was undigested (206-bp fragment). M: DNA marker; lanes 1, 4, and 7: CC; lanes 2, 5, and 8: CA; lanes 3 and 6: AA

\section{Results}

A total of 354 subjects including 185 PTB patients ( 72 males, 113 females, mean age: $50.0 \pm 19.6$ years) and 169 unrelated healthy subjects ( 75 males, 94 females, mean age: $47.9 \pm 15.0$ years) were evaluated. There was no statistically significant difference found between cases and controls regarding sex and age $(p>0.05)$. Genotypes and allele frequencies of FTO gene polymorphisms are shown in Table II. Allelic (A vs. T) and genotypic comparisons of codominant 
Table II. Genotype and allelic frequencies of FTO rs9939609 T>A and rs8050136 C>A variant in PTB patients and control subjects

\begin{tabular}{|c|c|c|c|c|}
\hline FTO polymorphism & Case $n(\%)$ & Control $n(\%)$ & OR $(95 \% \mathrm{CI})$ & $p$ \\
\hline \multicolumn{5}{|l|}{ rs9939609 $T>A$} \\
\hline \multicolumn{5}{|l|}{ Codominant } \\
\hline TT & $74(40.0)$ & $74(43.8)$ & 1.00 & - \\
\hline TA & $95(51.4)$ & $86(50.9)$ & $1.11(0.72-1.71)$ & 0.659 \\
\hline AA & $16(8.6)$ & $9(5.3)$ & $1.78(0.74-4.28)$ & 0.279 \\
\hline \multicolumn{5}{|l|}{ Dominant } \\
\hline TT & $74(40.0)$ & $74(43.8)$ & 1.00 & - \\
\hline $\mathrm{TA}+\mathrm{AA}$ & $111(60.0)$ & $95(56.2)$ & $1.17(0.76-1.78)$ & 0.518 \\
\hline \multicolumn{5}{|l|}{ Recessive } \\
\hline $\mathrm{TT}+\mathrm{TA}$ & $169(91.4)$ & $160(94.7)$ & 1.00 & \\
\hline AA & $16(8.6)$ & $9(5.3)$ & $1.68(0.72-3.92)$ & 0.299 \\
\hline \multicolumn{5}{|l|}{ Allele } \\
\hline $\mathrm{T}$ & $243(65.7)$ & $234(69.2)$ & 1.00 & - \\
\hline A & $127(34.3)$ & $104(30.8)$ & $1.18(0.86-1.61)$ & 0.354 \\
\hline \multicolumn{5}{|l|}{ rs8050136 C $>A$} \\
\hline \multicolumn{5}{|l|}{ Codominant } \\
\hline $\mathrm{CC}$ & $81(43.8)$ & $92(54.5)$ & 1.00 & - \\
\hline CA & $90(48.6)$ & 70 (41.4) & $1.46(0.95-2.25)$ & 0.100 \\
\hline AA & $14(7.6)$ & $7(4.1)$ & $2.27(0.87-5.90)$ & 0.107 \\
\hline \multicolumn{5}{|l|}{ Dominant } \\
\hline $\mathrm{CC}$ & $81(43.8)$ & $92(54.5)$ & 1.00 & - \\
\hline $\mathrm{CA}+\mathrm{AA}$ & $104(56.2)$ & $77(45.5)$ & $1.53(1.00-2.33)$ & 0.055 \\
\hline \multicolumn{5}{|l|}{ Recessive } \\
\hline $\mathrm{CC}+\mathrm{CA}$ & $171(92.4)$ & $162(95.9)$ & 1.00 & - \\
\hline AA & $14(7.6)$ & $7(4.1)$ & $1.89(0.74-4.81)$ & 0.186 \\
\hline \multicolumn{5}{|l|}{ Allele } \\
\hline $\mathrm{C}$ & $252(68.1)$ & $254(75.1)$ & 1.00 & - \\
\hline A & $118(31.9)$ & $84(24.9)$ & $1.42(1.02-1.97)$ & 0.045 \\
\hline
\end{tabular}

(TA vs. TT and AA vs. TT), dominant (TA+AA vs. TT), and recessive (AA vs. TA+TT) genetic inheritance models showed no significant association between rs9939609 T>A polymorphism and risk of PTB. Regarding rs8050136 C>A polymorphism, this variant marginally increased the risk of PTB in dominant $(\mathrm{OR}=1.53,95 \% \mathrm{CI}=1.00-2.33, p=0.055, \mathrm{CA}+\mathrm{AA}$ vs. $\mathrm{CC})$ inheritance model tested, where rs8050136 A allele significantly increased the risk of PTB $(\mathrm{OR}=1.42,95 \% \mathrm{CI}=1.02-1.97, p=0.045)$ compared with $\mathrm{C}$ allele.

The interaction of two polymorphisms on risk of PTB is shown in Table III. The results revealed that AA/AA genotype marginally increased the risk of PTB compared with rs9939609 TT/rs8050136 CC genotype.

Haplotype frequencies of FTO gene polymorphisms in PTB patients and controls are shown in Table IV. The results revealed that AA haplotype marginally associated with risk of PTB compared with rs9939609T/rs8050136C. 
Table III. Interaction of FTO rs9939609 T>A and rs8050136 C>A polymorphisms with PTB risk

\begin{tabular}{lccccc}
\hline rs9939609 T>A & rs8050136 C >A & PTB $n(\%)$ & Controls $n(\%)$ & OR (95\% CI) & $p$ \\
\hline TT & CC & $68(36.8)$ & $72(42.6)$ & 1.00 & - \\
TA & CA & $83(44.9)$ & $64(37.9)$ & $1.42(0.89-2.26)$ & 0.158 \\
TA & CC & $12(6.5)$ & $20(11.8)$ & $0.64(2.89-1.40)$ & 0.326 \\
AA & AA & $14(7.6)$ & $5(3.0)$ & $2.96(1.01-8.68)$ & 0.051 \\
TT & CA & $6(3.2)$ & $2(1.2)$ & $3.18(0.62-16.29)$ & 0.275 \\
AA & CA & $2(1.1)$ & $4(2.4)$ & $0.52(0.09-2.99)$ & 0.683 \\
TA & AA & $0(0.0)$ & $2(1.2)$ & - & - \\
\hline
\end{tabular}

Table IV. Haplotype association of FTO rs9939609 T>A and rs8050136 C>A variants with PTB risk

\begin{tabular}{lccccc}
\hline $\begin{array}{l}\text { rs9939609 } \\
\mathrm{T}>\mathrm{A}\end{array}$ & $\begin{array}{c}\text { rs8050136 } \\
\mathrm{C}>\mathrm{A}\end{array}$ & $\begin{array}{c}\text { PTB } \\
\text { (Frequency) }\end{array}$ & $\begin{array}{c}\text { Control } \\
\text { (Frequency) }\end{array}$ & OR (95\% CI) & $p$ \\
\hline $\mathrm{T}$ & $\mathrm{C}$ & 0.6397 & 0.6794 & 1.00 & - \\
$\mathrm{A}$ & $\mathrm{A}$ & 0.3019 & 0.2356 & $1.39(0.96-2.02)$ & 0.078 \\
$\mathrm{~A}$ & $\mathrm{C}$ & 0.0414 & 0.0721 & $0.64(0.32-1.28)$ & 0.210 \\
$\mathrm{~T}$ & $\mathrm{~A}$ & 0.0170 & 0.0129 & $1.48(0.40-5.41)$ & 0.560 \\
\hline
\end{tabular}

\section{Discussion}

Obesity is identified to affect cell-mediated immune responses. Recent studies have shown that genetic polymorphisms in the FTO gene are associated with human obesity. In the present study, we examined the possible association between FTO gene polymorphisms and the risk of PTB in a sample of Iranian population. Our findings revealed that rs 9939609 variant was not associated with the risk of PTB, whereas the rs8050136 C>A variant marginally increased the risk of PTB in dominant inheritance model. The rs 8050136 A allele significantly increased the risk of PTB compared with $\mathrm{C}$ allele. In contrast to our findings, Feng et al. [22] have found a significant association between FTO rs9939609 polymorphism and risk of TB. The AA genotype significantly increased the risk of TB compared with TT genotype $(\mathrm{OR}=3.77,95 \% \mathrm{CI}=2.26-6.28, p<0.001)$. Furthermore, the A allele increased the risk of TB $(\mathrm{OR}=1.26,95 \% \mathrm{CI}=1.08-1.48, p=0.004)$. But, they did not find an association between rs8050136 variant and risk of TB.

It has been proposed that obesity is a risk factor for cancer. Several studies have shown that FTO gene polymorphisms may be significantly associated with risk of various cancers $[25,26]$.

The effect of FTO gene variant on the risk of PTB may not merely be attributed to its role in the risk of obesity. The alteration of human immune response related to this genetic variant may play a role. 
The present study has several limitations. First, we have no data regarding body mass index prior to the diagnosis of tuberculosis, and we could not determine the effect of $F T O$ variants on obesity. Second, we only selected two variants in the FTO gene. Third, we did not determine the gene environmental interactions. Finally, we had no data regarding BCG vaccination of cases and controls.

In summary, our findings revealed an association between rs 8050136 variant of FTO gene and risk of PTB in a sample of Iranian population. The possible mechanisms that could explain this association remains to be clear. Further studies with larger sample sizes and different ethnicities are necessary to confirm these findings.

\section{Acknowledgements}

This work was funded by a dissertation research grant (M.D. thesis of ND \#7273) from Zahedan University of Medical Sciences. The authors would like to thank the patients and healthy subjects who willingly participated in this study.

\section{Conflict of Interest}

The authors declare no conflict of interest.

\section{References}

1. Lin, P. L., Flynn, J. L.: Understanding latent tuberculosis: A moving target. J Immunol 185, 15-22 (2010).

2. Oxlade, O., Schwartzman, K., Behr, M. A., Benedetti, A., Pai, M., Heymann, J., Menzies, D.: Global tuberculosis trends: A reflection of changes in tuberculosis control or in population health? Int J Tuberc Lung Dis 13, 1238-1246 (2009).

3. Zumla, A., George, A., Sharma, V., Herbert, N., Baroness Masham of Ilton: WHO's 2013 global report on tuberculosis: Successes, threats, and opportunities. Lancet 382, 1765-1767 (2013).

4. Hashemi, M., Sharifi-Mood, B., Nezamdoost, M., Moazeni-Roodi, A., Naderi, M., Kouhpayeh, H., Taheri, M., Ghavami, S.: Functional polymorphism of interferon-gamma (IFN-gamma) gene $+874 \mathrm{~T} / \mathrm{A}$ polymorphism is associated with pulmonary tuberculosis in Zahedan, Southeast Iran. Prague Med Rep 112, 38-43 (2011).

5. Hashemi, M., Sharifi-Mood, B., Rasouli, A., Amininia, S., Naderi, M., Taheri, M.: Macrophage migration inhibitory factor $-173 \mathrm{G} / \mathrm{C}$ polymorphism is associated with an increased risk of pulmonary tuberculosis in Zahedan, Southeast Iran. EXCLI J 14, 117-122 (2015). 
6. Bahari, G., Hashemi, M., Taheri, M., Naderi, M., Eskandari-Nasab, E., Atabaki, M.: Association of IRGM polymorphisms and susceptibility to pulmonary tuberculosis in Zahedan, Southeast Iran. Sci World J 2012, 950801 (2012).

7. Naderi, M., Hashemi, M., Hazire-Yazdi, L., Taheri, M., Moazeni-Roodi, A., EskandariNasab, E., Bahari, G.: Association between toll-like receptor2 Arg677Trp and 597T/C gene polymorphisms and pulmonary tuberculosis in Zahedan, Southeast Iran. Braz J Infect Dis 15, 516-520 (2013).

8. Naderi, M., Hashemi, M., Taheri, M., Pesarakli, H., Eskandari-Nasab, E., Bahari, G.: CD209 promoter $-336 \mathrm{~A} / \mathrm{G}$ (rs4804803) polymorphism is associated with susceptibility to pulmonary tuberculosis in Zahedan, southeast Iran. J Microbiol Immunol Infect 47, 171-175 (2014).

9. Shamsi, M., Zolfaghari, M. R., Farnia, P.: Association of IFN-gamma and P2X7 receptor gene polymorphisms in susceptibility to tuberculosis among Iranian patients. Acta Microbiol Immunol Hung 63, 93-101 (2016).

10. Fredriksson, R., Hagglund, M., Olszewski, P. K., Stephansson, O., Jacobsson, J. A., Olszewska, A. M., Levine, A. S., Lindblom, J., Schioth, H. B.: The obesity gene, FTO, is of ancient origin, up-regulated during food deprivation and expressed in neurons of feedingrelated nuclei of the brain. Endocrinology 149, 2062-2071 (2008).

11. de Heredia, F. P., Gomez-Martinez, S., Marcos, A.: Obesity, inflammation and the immune system. Proc Nutr Soc 71, 332-338 (2012).

12. Festa, A., D’Agostino, R., Jr., Williams, K., Karter, A. J., Mayer-Davis, E. J., Tracy, R. P., Haffner, S. M.: The relation of body fat mass and distribution to markers of chronic inflammation. Int J Obes Relat Metab Disord 25, 1407-1415 (2001).

13. Bullo, M., Garcia-Lorda, P., Megias, I., Salas-Salvado, J.: Systemic inflammation, adipose tissue tumor necrosis factor, and leptin expression. Obes Res 11, 525-531 (2003).

14. Karlsson, E. A., Beck, M. A.: The burden of obesity on infectious disease. Exp Biol Med (Maywood) 235, 1412-1424 (2010).

15. Choe, S. S., Huh, J. Y., Hwang, I. J., Kim, J. I., Kim, J. B.: Adipose tissue remodeling: Its role in energy metabolism and metabolic disorders. Front Endocrinol (Lausanne) 7, 30 (2016).

16. Ande, S. R., Nguyen, K. H., Gregoire Nyomba, B. L., Mishra, S.: Prohibitin-induced, obesity-associated insulin resistance and accompanying low-grade inflammation causes NASH and HCC. Sci Rep 6, 23608 (2016).

17. Fawcett, K. A., Barroso, I.: The genetics of obesity: FTO leads the way. Trends Genet 26, 266-274 (2010).

18. Albuquerque, D., Nobrega, C., Manco, L.: Association of FTO polymorphisms with obesity and obesity-related outcomes in Portuguese children. PLoS One 8, e54370 (2013).

19. Attaoua, R., Ait El Mkadem, S., Lautier, C., Kaouache, S., Renard, E., Brun, J. F., Fedou, C., Gris, J. C., Bringer, J., Grigorescu, F.: Association of the FTO gene with obesity and the metabolic syndrome is independent of the IRS-2 gene in the female population of Southern France. Diabetes Metab 35, 476-483 (2009).

20. Guclu-Geyik, F., Onat, A., Yuzbasiogullari, A. B., Coban, N., Can, G., Lehtimaki, T., Erginel-Unaltuna, N.: Risk of obesity and metabolic syndrome associated with FTO gene variants discloses clinically relevant gender difference among Turks. Mol Biol Rep 43, 485-494 (2016). 
21. Qi, L., Kang, K., Zhang, C., van Dam, R. M., Kraft, P., Hunter, D., Lee, C. H., Hu, F. B.: Fat mass-and obesity-associated (FTO) gene variant is associated with obesity: Longitudinal analyses in two cohort studies and functional test. Diabetes 57, 3145-3151 (2008).

22. Feng, Y., Wang, F., Pan, H., Qiu, S., Lu, J., Wu, L., Wang, J., Lu, C.: Obesity-associated gene FTO rs 9939609 polymorphism in relation to the risk of tuberculosis. BMC Infect Dis 14, 592 (2014).

23. Kouhpayeh, H. R., Hashemi, M., Hashemi, S. A., Moazeni-Roodi, A., Naderi, M., SharifiMood, B., Taheri, M., Mohammadi, M., Ghavami, S.: R620W functional polymorphism of protein tyrosine phosphatase non-receptor type 22 is not associated with pulmonary tuberculosis in Zahedan, Southeast Iran. Genet Mol Res 11, 1075-1081 (2012).

24. Hashemi, M., Hanafi Bojd, H., Eskandari Nasab, E., Bahari, A., Hashemzehi, N. A., Shafieipour, S., Narouie, B., Taheri, M., Ghavami, S.: Association of adiponectin rs 1501299 and rs266729 gene polymorphisms with nonalcoholic fatty liver disease. Hepat Mon 13, e9527 (2013).

25. Huang, X., Zhao, J., Yang, M., Li, M., Zheng, J.: Association between FTO gene polymorphism (rs9939609 T/A) and cancer risk: A meta-analysis. Eur J Cancer Care (Engl) (2016).

26. Zhao, J., Huang, X., Yang, M., Li, M., Zheng, J.: Association between the FTOrs 8050136 polymorphism and cancer risk: A meta-analysis. Fam Cancer 15, 145-153 (2016). 